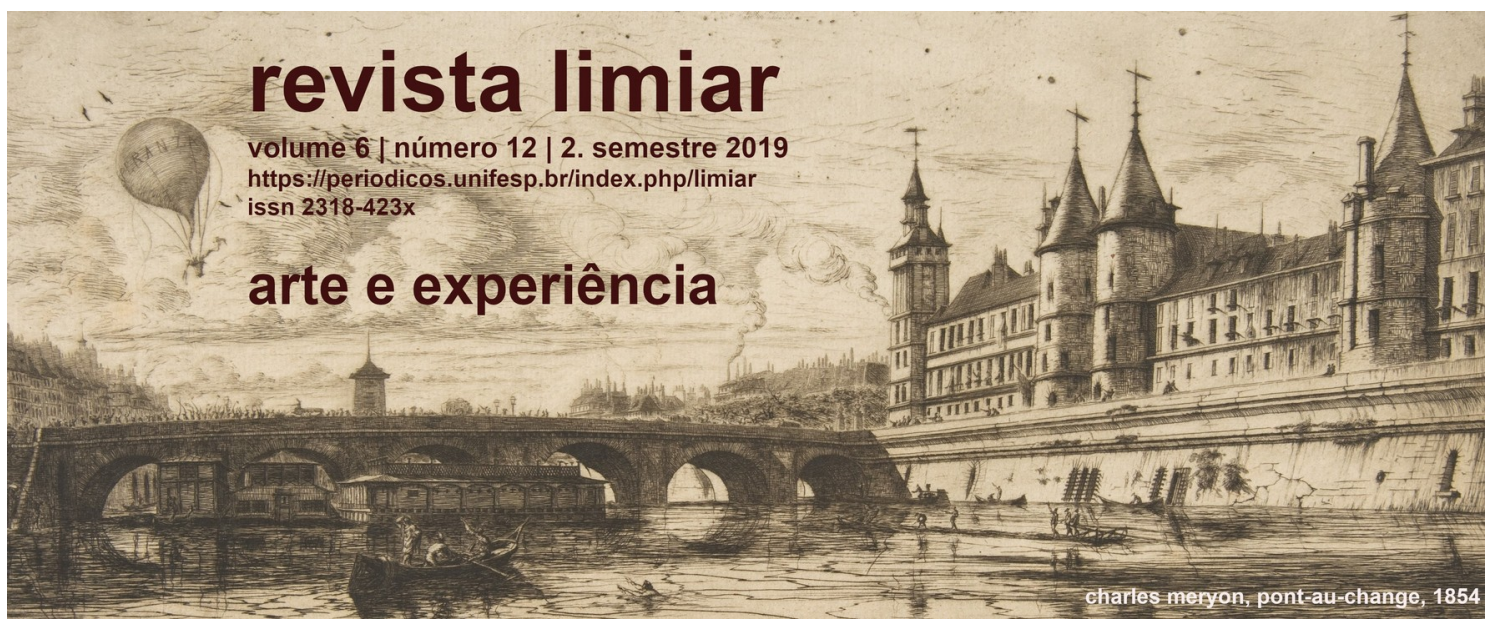

\title{
Proust a contrapelo: \\ experiência temporal, obra de linguagem e crítica materialista
}

\section{Luís Inácio Oliveira Costa*}

Resumo: Em sua leitura da obra de Marcel Proust, Benjamin reconhece como uma questão de fundo da Recherche du temps perdu a correlação fundamental entre experiência histórica e elaboração linguística, preocupação que se situa, na verdade, no núcleo do pensamento benjaminiano. O presente artigo busca deter-se nessa questão central para Benjamin, em especial como ela é enfrentada nas duas últimas partes do ensaio Para a imagem de Proust, no qual Benjamin faz já um exercício de crítica materialista. Para esse projeto crítico benjaminiano que se aprofunda ao longo dos anos de 1930, a obra de linguagem se destaca como um médium históricolinguístico no qual o ainda não expresso pode alcançar expressão. È por essa via que o experimento narrativo da Recherche busca ser lido por Benjamin numa espécie de procedimento crítico a contrapelo.

Palavras-chave: experiência histórica; obra literária; crítica; Walter Benjamin; Marcel Proust.

Abstract: In his reading of Marcel Proust's work, Benjamin recognizes as a matter of substance in Recherche du temps perdu the fundamental correlation between historic experience and linguistic elaboration, a concern that is actually situated in the core of the Benjaminian thinking. The present article aims to analyze this central issue to Benjamin, especially how it is confronted in the last two parts of the essay The Image of Proust, in which Benjamin already makes an exercise of materialistic criticism. To that Benjaminian critical project that deepens throughout the 1930s, the language work stands out as a historic-linguistic medium in which what is still not expressed can reach

\footnotetext{
* Professor adjunto do Departamento de Filosofia da Universidade Federal do Maranhão - UFMA. E-mail para contato: luisinacioc@uol.com.br.
} 
expression. It is through this way that the narrative experiment in Recherche searches to be read by Benjamin in a sort of critical procedure in reverse.

Keywords: historic experience; literary work; criticism; Walter Benjamin; Marcel Proust.

Muitos leitores de Walter Benjamin já chamaram a atenção para a importância da obra literária de Marcel Proust para o pensamento do crítico judeu-alemão. Mais do que uma influência identificável em alguns temas e questões com que Benjamin se ocupou, essa importância se traduziu, antes, numa relação tensa e complexa do crítico com o escritor, relação que talvez pudesse ser apreendida pela própria noção benjaminiana de constelação. Nesse sentido, o deslocamento da leitura de Proust para o terreno do pensamento historiográfico e para o esforço de construir novos modos de tratar o tempo histórico fora do modelo da progressão, tal como Benjamin se propôs a fazer, não significou uma mera transposição mas um efetivo deslocamento recriador e crítico; do mesmo modo, a leitura crítica experimental da obra de Proust empreendida por Benjamin, tanto imersão na condição histórico-linguística da obra quanto expansão dos limites convencionais da atividade crítica para além da mera ratificação da obra, terminou por conduzi-lo a uma articulação inovadora entre crítica literária e historiografia. Em seu embate com Proust, Benjamin soube reconhecer como uma questão de fundo proposta pela Recherche du temps perdu as interferências mútuas entre linguagem e temporalidade, entre experiência histórica e elaboração linguística, preocupação que se situa, na verdade, no núcleo do pensamento benjaminiano. Talvez essa seja uma das questões decisivas que se sobressai na constelação Benjamin-Proust. Gostaria de me deter aqui nessa questão tão importante para Benjamin, em especial como ela é instigantemente tratada nas duas últimas partes do ensaio Para a imagem de Proust.

Com efeito, depois do trabalho de tradução para o alemão de parte da Recherche em meados dos anos de 1920, em plena República de Weimar, Benjamin dedicou ao escritor francês o ensaio Para a imagem de Proust, publicado em 1929, na revista Die literarische Welt, um arrojado ensaio de crítica que se propunha a apresentar uma fisiognomia do escritor Proust em tensão com a sua obra inclassificável e, por via indireta, combater as interpretações empobrecedoras da obra, tanto as leituras psicologizantes francesas e as leituras estetizantes alemãs como as 
leituras puramente desqualificadoras, comungadas por certa esquerda literária, fosse ela francesa ou alemã. Mas o ensaio de 1929 também representou para Benjamin a possibilidade de um exercício experimental de crítica literária materialista, no contexto mesmo de seu propósito de recriação da crítica como gênero; para essa crítica materialista de forte caráter experimental, a leitura da obra proustiana não se faria pela exposição de uma tese interpretativa geral a ser desenvolvida mas seria construída, ao contrário, a partir da apresentação de múltiplos materiais de leituras destinados a compor uma fisiognomia da obra e a fornecer, com sua própria montagem, a leitura crítica.

Nesse ensaio de 1929 sobre Proust, a tensão entre experiência temporal e obra linguística se impunha para Benjamin como uma questão fundamental e ganharia ali uma formulação precisa e lapidar: "A imagem de Proust é a mais alta expressão fisionômica que a crescente discrepância entre poesia e vida poderia assumir. Eis a moral que justifica a tentativa de evocar essa imagem". ${ }^{1}$ É a própria tensão irresoluta entre existência vivida e obra literária que, para Benjamin, se encontra no núcleo da Recherche como a sua aporia. Assim, é mesmo o conceito moderno de literatura, ligado ao desenvolvimento da imprensa e à difusão da forma de transmissão do livro e, nessa medida, à constituição de uma esfera pública literária dependente da esfera do mercado e entrelaçada à privaticidade do mundo burguês, que deve ser situado no contexto da cisão moderna entre a subjetividade burguesa (com toda a sua expansão das vivências da interioridade e da intimidade) e a esfera de um mundo comum (com a sua redução às mídias da imprensa), cisão que Benjamin descreveu em termos de uma dissolução da experiência comum e transmissível, cuja forma literária mais representativa foi o romance moderno. Para Benjamin, o experimento literário da Recherche expressa aquela "crescente discrepância entre poesia e vida" em seus pontos mais extremos e delicados e tal como ela foi instaurada e produzida por essas transformações modernas da experiência. A Recherche assume, assim, a forma paradoxal da elaboração literária dessa discrepância entre poesia e vida a partir da função poética metamorfoseadora da narrativa como um trabalho de rememoração. Para Proust como para Benjamin ou, ainda, para o Proust lido por Benjamin, esse

1 BENJAMIN, Walter. A imagem de Proust. In: Obras escolhidas $I .8^{\mathrm{a}}$ ed. Trad. de Sérgio Paulo Rouanet com revisão de Márcio Selligman-Silva. São Paulo: Brasiliense, 20012. p. 37; Gesammelte Schriften II-1. Frankfurt am Main: Suhrkamp, 1991. p. 311. 
trabalho de rememoração corresponde a um trabalho de transformação significativa do passado.

No fim dos anos de 1930, já no contexto de sua investigação em torno de uma arqueologia da modernidade do século XIX e de sua leitura da obra de Baudelaire, Benjamin voltará a essa questão, a seu ver crucial, na Recherche de Proust. No início do ensaio de 1939 Sobre algum temas em Baudelaire, Benjamin assim descreve a aporia com a qual o narrador proustiano se encontra às voltas, qual seja, a de se ver impelido a construir artificialmente, com seu caudaloso romance, uma forma de dar forma narrativa à experiência vivida justamente nas condições modernas de desfalque da experiência comum e comunicável:

Pode-se considerar a obra de Proust, Em busca do tempo perdido, como a tentativa de reproduzir artificialmente, sob as condições sociais atuais, a experiência tal como Bergson a imagina, pois se poderá ter menos esperanças de realiza por meios naturais. ${ }^{2}$

E mais adiante, completa:

Os oito volumes da obra de Proust nos dão a ideia das medidas necessárias à restauração da figura do narrador para a atualidade. Proust empreendeu a missão com extraordinária coerência, deparando-se, desde o início, com uma tarefa elementar: fazer a narração de sua própria infância. Mensurou toda a dificuldade ao apresentar, como questão do acaso, o fato de poder ou não realizá-la. No contexto dessas reflexões forja o termo mémoire involontaire. Esse conceito traz as marcas da situação em que foi criado e pertence ao inventário do indivíduo multifariamente isolado. ${ }^{3}$

Lida a partir das reflexões benjaminianas em torno do declínio da narração no mundo moderno, a Recherche se inscreve emblematicamente no coração dos impasses do narrar na modernidade do fim do século XIX. É nesse contexto que Benjamin pode reconhecer na obra de Proust uma tentativa arrojada de recuperar a figura do narrador nas condições históricas adversas da alta modernidade, condições em que justamente a arte de narrar perdeu os seus esteios tradicionais de experiência comum e transmissível. Mas Proust pretende reabilitar a figura do narrador servindose, paradoxalmente, da forma do romance, o gênero literário característico da modernidade burguesa. Centrado nas vivências do indivíduo solitário e desorientado

2 BENJAMIN. Sobre alguns temas em Baudelaire. In: Obras escolhidas II. $3^{a}$ ed. Trad. de José Carlos Martins Barbosa et alii. São Paulo: Brasiliense, 1994. p. 105; GS I-2. Op. Cit. p. 609.

3 Id. Ibid. p. 107; Id. Ibid. p. 611. 
em sua busca de sentido, o romance constitui, na verdade, segundo o conhecido diagnóstico de Benjamin, um sintoma literário moderno das transformações nas formas de linguagem que conduziram ao declínio da narração tradicional. Proust se defronta precisamente com esse paradoxo narrativo do romance, paradoxo que Adorno sintetizou numa fórmula, por assim dizer, benjaminiana: "não se pode mais narrar, embora a forma do romance exija a narração". ${ }^{4}$ Parece-nos, no entanto, que a Recherche quer aprofundar mais ainda esse paradoxo narrativo, torná-lo um pouco mais arriscado e produtivo - em sua empreitada de construir uma narrativa que se baseie no trabalho da rememoração como uma espécie de recherche, ao mesmo tempo busca e pesquisa, Proust se vê às voltas com a exigência de uma forma outra de narrar; para tanto, ele apela ainda à forma narrativa do romance, mas, ao mesmo tempo, força os limites da forma romanesca clássica para que ela possa atender àquela tarefa de rememoração-investigação narrativa. Ora, do ponto de vista da inquietação de Benjamin com a crise da narração e com 'novas formas de tratar o passado', o gigantesco romance de Proust tem propriamente o sentido de uma recherche; em especial porque, desse ponto de vista, a experimentação proustiana com as possibilidades narrativas da forma do romance não se desliga da buscainvestigação de uma experiência de temporalidade diversa daquela instaurada pelas condições da modernidade - ou seja, uma experiência temporal que ainda possa constituir-se como história narrável e que, no entanto, não se reduza ao continuum e à platitude da cronologia, mas tenha antes a ver com a disrupção, a intensidade e a conjunção tensa de presente e passado na rememoração. É nesse sentido que o experimento da Recherche configura, conforme nota Gagnebin, uma tentativa de "reintroduzir, na vida moderna, a intensidade temporal de experiências liminares". ${ }^{5}$

A narrativa da Recherche se inicia, não por acaso, com as divagações do seu ainda incerto narrador em torno do adormecer e do despertar. O que se segue então é o longo e vão esforço do narrador de retomar as lembranças de sua infância na cidadezinha de Combray num movimento tateante que mistura a tentativa de recordação e o poder dissolvente do esquecimento. A irrupção da memória involuntária algumas páginas depois no famoso episódio da madeleine também se dá como vacilação entre o lembrar e o esquecer, como intervenção inesperada de uma

4 ADORNO, Theodor W. Posição do narrador no romance contemporâneo. In: Notas de literatura I. Trad. de Jorge de Almeida. São Paulo: Duas cidades/Ed. 34, 2003. p. 55.

5 GAGNEBIN, Jeanne Marie. Limiar: entre a vida e a morte. In: Limiar, aura e rememoração. Ensaios sobre Walter Benjamin. São Paulo: 34, 2014. p. 39. 
imagem poderosa do passado numa experiência sensorial do presente. Seja nas transições entre a vigília e o sono, seja nas intermitências do lembrar e do esquecer, do presente e do passado no movimento da rememoração, toda a narrativa da Recherche busca sustentar-se na frágil potência dessas experiências de limiar com sua temporalidade tensa, hesitante, tecida de complicações. Para Proust, esta se aparenta, no fim das contas, com a própria temporalidade da obra de arte, já que a criação artística constitui, também ela, uma construção liminar que depende tanto da consciência desperta quanto das experiências ligadas ao inconsciente e à memória involuntária.

Mas é somente na parte final de O tempo redescoberto, depois de um longo adiamento, que o narrador proustiano voltará a enfrentar o enigma da memória involuntária e buscará, enfim, Ihe decifrar o sentido. Na verdade, toda a primeira parte do derradeiro romance da Recherche apenas prolonga um pouco mais as experiências de desilusão do herói-narrador que se sucederam às narrativas de "Combray". Significativamente, essa primeira parte de O tempo redescoberto se inicia com um retorno à Tansonville, nos arredores da cidadezinha de Combray, o lugar primeiro de sua memória topográfica, a antiga paisagem onde se depositavam as suas lembranças da infância. Contudo, essa volta aos lugarejos de sua infância apenas provoca no herói-narrador desencanto, enfado e, por fim, indiferença e transforma também esses lugares em signos do temps perdu - na verdade, como observa Ricoeur ao ler essas páginas de O tempo redescoberto, a melancólica 'incuriosidade' do herói-narrador é por ele mesmo atribuída ao tempo que passa e dispersa tudo, ao Tempo como uma entidade que produz apenas devir e destruição e que se destaca inclusive do temps perdu. ${ }^{6}$

Esse desencantamento se estende, no entanto, também à sua antes acalentada vocação de escritor e, por fim, à própria literatura. Decepção final com a literatura que é encenada em $O$ tempo redescoberto pela leitura dos trechos inéditos do diário dos irmãos Goncourt, na verdade um pastiche crítico de Proust dirigido contra o enganoso de uma literatura pretensamente realista e contra a confusão da recordação memorialística com a reprodução fiel do acontecido. Em sua melancólica decepção depois da leitura das páginas do diário dos Goncourt, o herói ainda se inquieta diante do sentido ali atribuído à literatura e chega mesmo a contrapor

6 RICOEUR, Paul. Tempo e narrativa II. A configuração do tempo na narrativa de ficção. Trad. de Márcia Valéria Martinez de Aguiar. São Paulo: Martins Fontes, 2012. p. 247. 
documento histórico e arte, pois, retruca ele, "o que pode ter uma importância documental e até histórica (...) não é necessariamente uma verdade artística". ${ }^{7}$ Mas ao final prevalece o desencanto como "a mentira da literatura", com a sua redução a uma inócua reprodução da realidade, com o seu fracasso em apreender aquilo que de mais singular e fugaz se entremostrava nas experiências vividas - e como resultado imediato desse desencanto há a decisão de abandonar o vago projeto de se dedicar à escrita de um livro.

É somente quando o personagem-narrador, recém-saído de uma das casas de saúde onde se recolheu por alguns anos, resolve ir a uma recepção na mansão dos Guermantes que ele terá de novo a oportunidade de retomar a sua indagação sobre o enigma da memória involuntária e também sobre o sentido da literatura e da sua vocação de escritor, logo após uma sequência vertiginosa de eventos rememoradores semelhantes ao da madeleine, o primeiro deles já na chegada da mansão, ao tropeçar numa laje desigual que lhe traz à lembrança a cena de outro tropeço acontecido anos atrás no batistério de São Marcos em Veneza. São mais uma vez os eventos banais e as conjunções inesperadas da memória involuntária que permitirão ao herói-narrador pesquisar, numa recherche última e decisiva, o significado secreto da memória involuntária e, a partir daí, reapoderar-se do sentido e da vocação da literatura -

Porém é, às vezes, no justo momento em que tudo nos parece perdido, que ocorre o aviso que nos pode salvar; batemos a todas as portas que não abrem para nada, e na única pela qual podemos entrar, e que teríamos buscado em vão durante um século, esbarramos por acaso e ela se abre. ${ }^{8}$

A investida da memória involuntária termina por conduzir ao episódio da biblioteca de Guermantes - para não interromper a execução de uma peça musical já iniciada, o herói é convidado por um mordomo a aguardar um pouco num salãobiblioteca e ali, ainda sob o efeito da rememoração detonada pelo passo em falso na laje, pelo barulho de uma colher contra um prato e pela textura de um guardanapo engomado, ele resolve parar um pouco para meditar sobre o que se escondia no fundo de todas aquelas impressões rememoradoras. A rigor, nem se pode dizer que se trate de um episódio porque nele nada acontece além dos efeitos da memória involuntária;

7 PROUST, Marcel. Em busca do tempo perdido. O tempo recuperado. Trad. de Fernando Py. Rio de Janeiro: Ediouro, 2002. À la recherche du temps perdu. Le temps retrouvé. Vol. IV. Paris: Gallimard, 1989. p. 297.

8 Id. Ibid. p. 661; Id. Ibid. p. 445. 
até mesmo o reencontro na estante da biblioteca de um livro de sua infância - o François le champi - se revela, também ele, um novo acontecimento fortuito desse rememorar. O assim chamado episódio da biblioteca de Guermantes se resume, de fato, a essa digressão meditativa: é nele que se condensa aquilo que foi muitas vezes designado de uma 'teoria estética' - "uma grande dissertação sobre a arte" ${ }^{9}$ - como que embutida por Proust no interior do romance, num conhecido procedimento proustiano de interpolar de modo propositalmente ambíguo o ensaio reflexivo na narrativa de ficção.

É, desse modo, no episódio da biblioteca de Guermantes que o narrador proustiano resolve retomar a questão até então sem resposta da memória involuntária com seus momentos de felicidade inefável e, no entanto, essa "pesquisa outrora adiada"10 é agora conduzida a uma meditação sobre o tempo e não menos, como o seu coroamento, a uma meditação sobre a arte. A conclusão a que o narrador proustiano chega a certa altura de sua especulação é que o milagre da conjunção inesperada de dois momentos tão distantes, tal como promovido pela memória involuntária, não passava, na verdade, de um mecanismo fortuito - "um subterfúgio" destinado a the permitir experimentar, isolar e fixar "uma fração de tempo em estado puro". ${ }^{11}$ Assim, o que o narrador proustiano reconhece no fundo da experiência contingente e fugidia da memória involuntária é, paradoxalmente, a suspensão do próprio tempo - de um lado, a saída momentânea da ordem comum da cronologia, a vertigem da supressão do tempo sucessivo e linear para a qual o narrador emprega o termo "extratemporal"12; de outro, a partir do gozo desse instante revestido de eternidade, o vislumbre de uma forma de "tempo puro", liberto, enfim, das contingências do tempo que descompõe e devasta. Na verdade, todas as formulações de que esse narrador meditativo lança mão para descrever o instante de suspensão temporal e a emergência de um tempo puro apenas aprofundam o paradoxo, apenas expõem na linguagem a aporia de pretender escapar ao tempo ("um minuto livre da ordem do tempo" ${ }^{\prime 13}$ ) e reunir-se a uma substância eterna e intemporal a partir do gozo de um instante único e, no entanto, fugaz, ou seja, a partir da experiência do próprio

9 RICOEUR, Paul. Tempo e narrativa II. Op. Cit. p. 250.

10 PROSUT, Marcel. PROUST, Marcel. O tempo recuperado. Op. Cit. p. 665; Le temps retrouvé. Op. Cit. p. 449.

11 Id. Ibid. p. 666; Id. Ibid. p. 451.

12 Id. Ibid. p. 665; Id. Ibid. p. 450.

13 Id. Ibid. p. 666-667; Id. Ibid. p. 451. 
tempo ${ }^{14}$ Contudo, ao final da sua meditação o narrador proustiano encontrará na obra de arte a resposta para o paradoxo de uma eternidade experimentada apenas na fugacidade de um instante. A obra de arte constitui, por isso mesmo, o índice concreto e privilegiado do temps retrouvé, pois é somente pela fixação desse supremo e fugidio momento numa "obra durável" que toda experiência temporal e perecível - todo o temps perdu - poderá converter-se, por fim, em tempo redescoberto.

Essa solução artística que conclui a "teoria estética" da biblioteca de Guermantes também abre caminho para a retomada pelo herói-narrador do sentido da literatura e da sua própria vocação de escritor. Pois é a partir dessa solução artística para o paradoxo da experiência temporal que se dá a sua reconversão à escrita e ele se decide a escrever o seu livro. Mas logo depois dessas conclusões de sua meditação sobre o tempo e a arte, o herói-narrador, chamado ao salão da festa, é ali exposto ao espetáculo do poder de destruição do tempo nos rostos e corpos dos convidados e, mais radicalmente, à ameaça da morte que também lhe alcança, a ele próprio e à obra que pretende escrever. ${ }^{15}$ Ao final, a "obra durável", destinada a fixar o essencial das experiências vividas e reter algum sentido em meio à dissolução produzida pelo temps perdu, revelava-se, também ela, um fragmento constituído de tempo, uma obra que tomava o próprio tempo como sua matéria inescapável. As últimas palavras do narrador em $O$ tempo redescoberto reafirmam, na verdade, o impasse temporal, não apenas porque a obra anunciada se mantem até o fim sob o signo do tempo e sob a ameaça da morte, mas também porque a própria Recherche se configura, do seu tateante começo até o seu desfecho deixado em aberto, como a encenação narrativa desse embate insolúvel entre o temps retrouvé e o temps perdu, entre a obra tecida e a experiência temporal, entre a escrita e a morte.

Para Benjamin, no entanto, o mais relevante na Recherche de Proust não é o movimento de restauração do temps perdu pela conversão do perecível e do transitório na ordem duradoura da obra de arte e sim a reconfiguração desse embate

14 Cf. a respeito a leitura de Blanchot. BLANCHOT, Maurice. O livro por vir. Trad. de Leyla PerroneMoisés. São Paulo: Martins Fontes, 2005. P. 16-17.

15 É com espanto que o narrador proustiano descreve o não reconhecimento pelo herói dos rostos e corpos que conhecera no passado e guardara na memória daqueles rostos e corpos com que ele se deparava ali no salão da festa, mistura de baile de máscaras e dança macabra: "Um teatro de fantoches, onde, para se identificarem as pessoas conhecidas, fazia-se necessário decifrar, a um só tempo, vários planos situados por detrás delas, e que lhes conferiam profundidade, obrigando a um trabalho mental, pois devia-se ver esses velhos fantoches tanto com os olhos quanto coma memória; um teatro de fantoches banhados nas cores imateriais dos anos, exteriorizando o Tempo, o Tempo que de hábito é invisível, que, para deixar de sê-lo, procura corpos e, onde quer que os encontre, deles se apodera a fim de mostrar, acima deles, a sua lanterna mágica". Id. Ibid. p. 704; Id. Ibid. p. 503. 
insolúvel em narrativa sem que isso signifique a superação do tempo num síntese abstrata e enganosa; mais ainda: a incorporação da tensão aporética entre o tempo vivido e o tempo rememorado na própria composição da obra, de modo que ela se configure como exposição narrativa das contradições exasperadas do tempo histórico. Nesse sentido, para ele, importa menos o platonismo artístico que se extrai da alongada meditação do narrador na biblioteca de Guermantes, com seu fraseado idealista (o 'extratemporal', 'uma fração de tempo em estado puro') e sua pretensão de escapar à "ordem do tempo", que a reafirmação ao longo de todo o itinerário da Recherche da constituição histórica dos acontecimentos humanos e da espessura temporal própria às obras que daí nascem, já que este é, na verdade, o motivo central subjacente ao romance de Proust. Há, pois, na Recherche, segundo os termos da comentadora Krista Greffrath, um irônico dilema interno entre a sua "filosofia restauradora" exposta em O tempo redescoberto e "a lei estética" que preside a construção da narrativa - a filosofia idealista da restauração do temps perdu por força da obra de arte não encontra uma imediata correspondência no princípio construtivo da rememoração narrativa com suas tensões dialéticas incorporadas à própria forma do romance. Na verdade, a interpolação do episódio meditativo da biblioteca de Guermantes no interior da narrativa confere um acento irônico à tensão entre os ideais da filosofia da arte do personagem-narrador e o inacabamento do tempo histórico que a construção da obra quer incorporar. "Benjamin não adota a filosofia restaurativa do romance proustiano mas a lei estética de produção da recherche", conclui Greffrath. ${ }^{16}$

Ora, a última parte do ensaio sobre Proust é em grande medida dedicada a tematizar essa figura temporal da Recherche e explicitar, a partir da visada e das preocupações de Benjamin, a modalidade de configuração da temporalidade que está em jogo na rememoração proustiana. De algum modo, Benjamin retoma e reelabora aqui o tema da temporalidade própria à rememoração involuntária já delineado na primeira parte do ensaio. Para tanto, ele toma de empréstimo uma formulação do crítico literário Ramon Fernandez e quer, assim, pôr-se à distância de toda leitura que reforçasse na Recherche a visão platonizante como a sustentada pelo próprio narrador proustiano na 'teoria estética' da biblioteca de Guermantes. O propósito de Benjamin no ensaio é mesmo ler Proust a contrapelo desse platonismo artístico - "Com razão, Fernandez distinguiu, em Proust, um thème de l'eternité de um thème du temps. Mas

16 GREFfRATH, Krista. Proust et Benjamin. In: WISMANN, Heinz. Benjamin et Paris. Paris: Cerf, 1986. p. 121. 
essa eternidade não é de modo algum platônica ou utópica: ela pertence ao registro da embriaguez". ${ }^{17}$

Assim, a temporalidade tensa e intensiva instaurada pelas colisões e conjunções da rememoração involuntária não corresponde à emergência no seio da experiência temporal de uma eternidade transcendente e prenunciadora da obra de arte, mas, antes, à experiência temporal da embriaguez, experiência de interrupção da temporalidade ordinária da cronologia. Mais uma vez Benjamin descreve a rememoração posta à prova na Recherche em termos de uma experiência temporal de limiar, pois, assim como o rememorar involuntário dos episódios da madeleine e de $O$ tempo redescoberto e o despertar das primeiras páginas de "Combray", também a embriaguez instaura uma zona indecisa entre a atenção consciente e a percepção inabitual e, por isso mesmo, inclui-se entre os experimentos de iluminação profana e os fenômenos de criação mimética de correspondências. ${ }^{18} \mathrm{~A}$ alusão aqui à embriaguez tem, com efeito, a função de nos introduzir naquela modalidade disruptiva de temporalidade que se encontra na origem da rememoração narrativa da Recherche e dá a ela a sua configuração; à revelia das reflexões do narrador proustiano em $O$ tempo redescoberto, essa estrutura temporal não tem a ver, para Benjamin, com a pretensão de abolir o tempo mediante a abstração de um ideal e sim com uma configuração nova do tempo como entrecruzamento (die Verschränkung). Nesse sentido, se "embora sobrevivam, de fato, em Proust alguns traços de idealismo" ressalva Benjamin - "não são eles que determinam a significação dessa obra". ${ }^{19} \mathrm{Com}$ efeito, não são os resquícios de platonismo que se deixam ver exemplarmente na 'teoria estética' da biblioteca de Guermantes que, para o crítico, definem a obra; é, antes, na configuração da temporalidade posta à prova no romance que reside a sua mais alta significação. Esse mundo configurado na Recherche a partir da formação de tensas constelações temporais Benjamin o denominou de "universo do entrecruzamento" (Universum der Verschränkung).

A eternidade (die Ewigkeit) que Proust nos faz vislumbrar não é a do tempo infinito, e sim a do tempo entrecruzado (ist die verschränkte, nicht die

17 BENJAMIN, Walter. A imagem de Proust. In: Obras escolhidas I. Op. cit. p. 46; GS II-1. Op. Cit. p. 320. 18 Cf. a respeito BENJAMIN. O surrealismo. O último instantâneo da inteligência europeia. In: Obras escolhidas I. Op. Cit. p. 33-34; Der Sürrealismus. Die letzte Momentaufnahme der europäischen Intelligenz. In: GS II-1. p. 307-308. Cf. também BENJAMIN. Haxixe. Trad. de Flávio de Menezes e Carlos Nelson Coutinho. São Paulo: Brasiliense, 1984; Protokolle zu Drogenversuchen. In: GS VI. p. 558-618. 19 BENJAMIN. A imagem de Proust. In: Obras escolhidas I. Op. cit. p. 46; GS II-1. Op. Cit. p. 320. 
grenzenlose Zeit). Seu verdadeiro interesse é consagrado ao fluxo do tempo sob a sua forma mais real, e por isso mesmo mais entrecruzada (verschränkten Gestalt), que se manifesta de maneira mais direta na rememoração (im Erinnern) (internamente) e no envelhecimento (im Altern) (externamente). Acompanhar a interação entre envelhecimento e rememoração significa penetrar no coração do mundo proustiano, o universo do entrecruzamento (Universum der Verschränkung). É o mundo em estado de semelhança (die Welt im Stand der Ähnlichkeit), e nele reinam as 'correspondências', captadas primeiro pelos românticos, e do modo mais íntimo por Baudelaire, as que Proust foi o único a incorporar em nossa vida vivida. É esta a obra da mémoire involontaire, da força rejuvenescedora capaz de enfrentar o implacável envelhecimento. ${ }^{20}$

É desse modo que Benjamin caracteriza o universo proustiano da rememoração involuntária como um mundo regido pelas relações de semelhança, pelas correspondances que põem em conjunção tempos distantes, pelas tensões temporais que não encontram descanso e solução. Mas, por essa sua leitura de Proust, ele quer também recuperar a vinculação fundamental entre linguagem e temporalidade e, mais precisamente, estabelecer uma correlação, para ele decisiva, entre a dimensão mimética da linguagem e a configuração de uma temporalidade do entrecruzamento. Na verdade, o modo de configuração no trabalho de rememoração da Recherche obriga que se formule uma figura da temporalidade que não a da sucessão cronológica (a do 'tempo homogêneo e vazio', dirá Benjamin nas teses Sobre o conceito de história). Não se trata, pois, para ele, da abolição ou supressão do tempo graças à fuga para uma suposta eternidade transcendente da obra de arte. Também não se trata de um tempo infinito que se recusa a enfrentar a negatividade e a morte. O que está em jogo na Recherche é - diria ainda Benjamin - uma modalidade imanente de eternidade ou, antes, uma condensação temporal que se realiza pela criação de similitudes e correspondências por força mesmo do trabalho da rememoração. Esse trabalho (Arbeit) de rememoração se inscreve, ele próprio, no tempo histórico de uma existência e é em sua constituição histórica que ele apela por sua transformação em obra (Werk). Contudo, essa transformação do trabalho de rememoração em obra somente pode realizar-se pela incorporação da espessura temporal e histórica da existência vivida na obra. A eternidade proustiana diz respeito, no fim das contas, a essa incorporação da existência histórica na obra. A condensação de tensões temporais e a configuração do tempo histórico de uma existência em seu movimento contraditório fazem dessa eternidade imanente um tempo entrecruzado e

20 Id. Ibid. p. 46-47; Id. Ibid. p. 320. 
configuram a Recherche como "o universo do entrecruzamento". Uma vez que o trabalho e a obra da rememoração involuntária não se realizam como restauração, como repetição do passado no presente, como identificação do passado ao presente mas como criação de correspondências temporais, o universo de tempos entrecruzados forjado por essa rememoração obedece antes à "categoria da relação" que ao princípio de "identidade". ${ }^{21} \mathrm{Na}$ existência vivida, o entrecruzamento de tempos se expressa em sua forma externa no envelhecimento - os rostos e corpos trabalhados pelo tempo com os quais o herói-narrador se defronta na recepção de Guermantes expõem em suas metamorfoses a interpenetração de múltiplos tempos, a concentração de diferentes camadas históricas. Internamente, é o movimento da rememoração, análogo ao da criação mimética do semelhante pela linguagem, que produz o entrecruzamento de tempos diversos - a rememoração involuntária não repete ou reproduz o passado tal qual ele foi, ela cria, antes, similitudes inesperadas e assim promove a interpenetração de tempos e lugares afastados por distâncias até então intransponíveis. Em "Combray", o entrecruzamento da rememoração ganha uma figuração propriamente topográfica, o do cruzamento dos caminhos diversos de Swann e de Guermantes; em O tempo redescoberto, "o entrelaçamento dos caminhos" se dá pela rememoração que se apoia também numa figura concreta, a filha de Gilberte e Saint-Loupe, que promove o cruzamento dos dois antigos 'lados'. A condensação de tempos entrecruzados se realiza, pois, por um procedimento de presentificação e não por uma reflexão abstrata; por meio dessa presentificação de múltiplos tempos que se cruzam e se interpenetram, é possível ter acesso a uma experiência temporal que não se alcançaria viver nos limites temporais de uma única existência. ${ }^{22} \mathrm{~A}$ função da condensação temporal e da incorporação da história à obra é essa também. Condensação temporal e justaposição da multiplicidade da matéria histórica assinalam de igual modo modalizações outras de temporalidade que não se subsumem ao continuum e à progressão mas incluem a intensidade, a aceleração, a descontinuidade, a heterogeneidade, a inovação ou - aponta Benjamin - o "rejuvenescimento": "Mas justamente essa concentração (diese Konzentration) na qual se consome, com a velocidade de um relâmpago, aquilo que de outra forma murcharia

21 GREFFRATH, Krista. Metaphorischer materialismus. Untersuchungen zum Geschichtsbegriff Walter Benjamins. München: Wilhelm Fink, 1981. p. 71.

22 Benjamin assim o formula: "O procedimento de Proust não é a reflexão, mas a presentificação (Vergegenwärtigung). Pois ele se encontra permeado pela verdade de que não temos tempo de viver os verdadeiros dramas da existência que nos é destinada". BENJAMIN. A imagem de Proust. In: Obras escolhidas I. Op. cit. p. 47; GS II-1. Op. Cit. p. 320. 
e se extinguiria gradualmente, chama-se rejuvenescimento (Verjüngung)". ${ }^{23}$ Essa presentificação concentrada e justaposta de tempos diversos que se entrecruzam tem o efeito disruptivo de uma "desordem criativa", forma de reconfiguração que num fragmento do caderno $\mathrm{H}$ das Passagens Benjamin atribuirá à rememoração involuntária mas também à ordenação subversiva dos objetos pelo colecionador "Uma espécie de desordem produtiva (produktiver Unordnung) é o cânon da mémoire involontaire assim como do colecionador". ${ }^{24}$

Ora, por essa leitura da Recherche como um universo de tempos entrecruzados e como "um mundo em estado de semelhança", Benjamin pretende também por à prova, para o seu próprio pensamento, um modo novo de tratar o tempo histórico em estreita conexão com uma teoria mimética da linguagem, o que será persistentemente retomado em diferentes trabalhos dos anos de 1930, tanto, explicitamente, nos ensaios paralelos da Doutrina das semelhanças e Sobre a faculdade mimética, quanto, de modo mais indireto, em sua teoria da história e da narração de $O$ narrador e das teses Sobre o conceito de história - de algum modo, a noção aberta de imagem dialética, da historiografia materialista do fim dos anos de 1930, resulta também dessa articulação entre uma concepção mimética da linguagem e uma nova compreensão da temporalidade histórica. É por esse movimento mesmo da leitura crítica que Benjamin se apropria da noção proustiana de rememoração involuntária e a transforma para os fins de sua própria reflexão sobre a significação do tempo histórico. Nesse ponto, o trabalho da crítica literária extrapola o comentário e a interpretação da obra para converter-se num experimento de pensamento no mediumde-reflexão da obra em consonância com a leitura que Benjamin fez da concepção de crítica dos românticos. Em seu caráter experimental, o ensaio de 1929 sobre Proust contém assim elaborações esparsas de uma filosofia materialista da história que ganharão seus desdobramentos e desenvolvimentos nos trabalhos do fim dos anos de 1930, os ensaios sobre Baudelaire e os escritos ligados ao projeto das Passagens. Além disso, como os ensaios sobre Baudelaire, o ensaio sobre Proust já testa uma articulação experimental entre crítica literária e historiografia materialistas - a obra de Proust adquire então o sentido de um medium histórico-literário que oferece elementos novos para tratar o tempo histórico mas que também, como a obra poética de

23 Id. Ibid.; Id. Ibid.

24 BENJAMIN. Passagens. Trad. de Irene Aron. Belo Horizonte/São Paulo: UFMG/Imprensa oficial, 2006. p. 246; Das Passagen-Werk. GS V-1. p. 280. 
Baudelaire, contém inscrições históricas precisas que o integram à investigação de uma arqueologia da modernidade. Não é por outro motivo que a leitura da obra proustiana será também mobilizada em favor da investigação historiográfica materialista do fim dos anos de 1930. Essas mobilizações e deslocamentos inovadores participam, aliás, do modo de proceder dessa historiografia -"um pequeno exemplo de análise materialista, mais valioso que a maioria das coisas que existem nesse domínio", informa Benjamin ao citar um trecho do ensaio de Proust $A$ propósito do estilo de Flaubert num fragmento do caderno $\mathrm{K}$ do livro das Passagens. ${ }^{25}$

Nessa sua qualidade de um medium histórico-literário, a Recherche é lida por Benjamin como a obra que deu elaboração literária às transformações convulsas da passagem do século XIX para o século XX, com a dissolução final das sobrevivências feudais na Europa ocidental e a consolidação da moderna sociedade burguesa, mas também com as mudanças estéticas, linguísticas e midiáticas que marcaram esse período de transição. É significativo para Benjamin que Proust se sirva da composição inovadora de duas formas literárias com importantes funções expressivas na sociedade burguesa, o relato memorialístico e o romance, e o faça para historiar em seus mais íntimos mecanismos, em seus meandros mais triviais, as contradições que presidem o funcionamento da sociedade burguesa estabelecida (porque também as épocas históricas - lembra Benjamin - têm a sua "maneira inocente, ou antes, astuciosa e frívola, de comunicar seu segredo mais íntimo ao primeiro desconhecido"26). Com efeito, para Benjamin, "não foram nem Zola nem Anatole France, mas o jovem Proust, o esnobe sem importância, o trêfego frequentador de salões, quem ouviu, de passagem, do século envelhecido (...) as mais admiráveis confidências". ${ }^{27}$ E ele continua: "Somente Proust fez do século XIX um século digno de memórias. O que era antes dele um simples período temporal, desprovido de tensões, converteu-se num campo de forças, no qual foram despertas as mais variadas correntes de autores mais tardios". 28

Não se deve perder de vista aqui os propósitos de Benjamin em arriscar uma leitura política materialista de Proust, de modo mais contundente na segunda parte do ensaio. Esses propósitos não se dissociam, por certo, da intenção de apresentar a

25 Id. Ibid. p. 439; Id. Ibid. p. 439.

26 BENJAMIN. A imagem de Proust. In: Obras escolhidas I. Op. cit. p. 41; Zum Bilde Prousts. In: GS II-1. p. 314.

27 Id. Ibid. p. 41; Id. Ibid. p. 314-315.

28 Id. Ibid; Id. Ibid. 
fisiognomia da obra proustiana para o público leitor de uma revista que abriga justamente o pensamento da esquerda intelectualizada da República de Weimar e quando há sérias dúvidas quanto ao interesse que Proust possa despertar para um debate literário de esquerda - "(...) Benjamin não escreve seu artigo para si mesmo" observa quanto a isso Robert Kahn - "mas para o leitor de um grande hebdomadário de esquerda da República de Weimar". ${ }^{29}$ Também não se pode esquecer aqui o pouco apreço e mesmo a resistência da esquerda literária da época em relação a Proust. Do ponto de vista de certa crítica literária politizada, o escritor francês, ainda pouco lido na Alemanha, era facilmente identificado a uma literatura burguesa decadente, quando não inteiramente ignorado. Benjamin escreve, portanto, o seu ensaio não apenas em confronto com a crítica acadêmica alemã mas também em oposição a um tipo de crítica literária de esquerda que se baseava nas interpretações esquemáticas do 'marxismo vulgar' e, conforme observa ironicamente Kahn, confundia Proust e Joyce no mesmo rol dos escritores sem qualquer interesse para a revolução. ${ }^{30}$

Mas é possível reconhecer também nessa estratégia de leitura do ensaio sobre Proust o esforço de articulação entre crítica literária e historiografia materialistas. $\mathrm{Na}$ medida em que as silenciosas convulsões históricas do século XIX alcançaram na obra de Proust uma expressão literária, essa obra se converte também no medium-deexposição de figurações poéticas do inconciliado e do esquecido e o crítico literário assume também a tarefa do historiador materialista de ler no medium da obra os sintomas e signos daquilo que até então restou silenciado e sem expressão. Assim, é mediante o esforço de uma crítica-historiografia materialista e a contrapelo da vulgarização crítica de esquerda que Benjamin se propõe a ler Proust com as preocupações políticas que orientavam o seu pensamento naquele período de guinada materialista. Dessa perspectiva, a fisiognomia histórica do fim do século XIX apresentada pela Recherche é a de "uma sociedade saturada" na qual a burguesia triunfante busca assimilar-se aos ideais e códigos da aristocracia e a nobreza feudal decadente busca manter-se a todo custo com suas insígnias nas novas condições da sociedade burguesa - "Agora, porém, fica evidente que os problemas dos homens proustianos provêm de uma sociedade saturada (einer saturierten Gesellschaft). Mas

29 KAHN, Robert. Images, passages: Marcel Proust et Walter Benjamin. Paris: Kimé, 1998. p. 80.

30 Id. Ibid. Sobre esse ponto adverte Benjamin: "Nada disso valeria a pena discutir (...), não fosse a displicência da crítica alemã. (...) Seus veteranos representantes apressaram-se a atribuir ao próprio Proust o esnobismo do meio por ele descrito. E a caracterizar sua obra como uma questão interna francesa, como um apêndice frívolo do Almanaque de Gotha". BENJAMIN, Walter. A imagem de Proust. In: Obras escolhidas I. Op. cit. p. 41; GS II-1. Op. Cit. p. 314. 
não há, entre eles, um único sequer que coincida com os problemas do autor. Estes são subversivos". ${ }^{31}$

Na verdade, Benjamin não chega a desenvolver uma análise dessa "sociedade saturada" tal como ele a reconhece na obra de Proust. Contudo, nas anotações preparatórias ao ensaio ele dá a essa problemática uma importante explicitação. Com efeito, é na interpretação de Georg Lukács para o desenvolvimento contraditório do capitalismo industrial, em seu História e consciência de classe, que Benjamin recolhe essa problemática, mais precisamente no desdobramento que Lukács dá à tese de Marx segundo a qual, no apogeu do capitalismo, a consciência de classe da burguesia é conduzida a uma contradição insolúvel. Para Lukács, o impasse histórico da burguesia reside no fato de ela ainda não ter triunfado sobre o sistema produtivo que Ihe precedeu, ou seja, o feudalismo, quando o seu novo inimigo, o proletariado, já se anuncia no horizonte da história. Na sua leitura de Proust, Benjamin leva um pouco mais adiante esse desdobramento da tese marxiana por Lukács:

Mas a aparição do proletariado muda também a situação estratégica na linha de frente contra o feudalismo. A burguesia deve encontrar aí um arranjo a qualquer preço, refugiar-se por trás das posições do feudalismo, menos contra o avanço do proletariado que contra a voz de sua própria consciência de classe.

E completa: "Essa é a posição da obra proustiana. Seus problemas provêm de uma sociedade saturada, mas as soluções que ela oferece são subversivas". ${ }^{32}$

Para Benjamin, o que a Recherche encena e ao mesmo tempo radiografa com cuidado minucioso é a estratégia mimética da burguesia de assimilar-se à atitude da aristocracia nos estertores da ordem feudal e no auge das contradições produzidas pela sociedade capitalista industrial. Por isso mesmo, o escape da burguesia "em direção ao passado, sua reassimilação pela nobreza" é, segundo Benjamin, "o tema sociológico" que subjaz à Recherche. ${ }^{33}$ No entanto, a essa dialética da assimilação das contradições de classe no auge do capitalismo industrial também estará sujeita a renitente aristocracia: pela via inversa, também ela, destituída de seus antigos privilégios de classe, precisará aliar-se, pela última vez, à burguesia, detentora do poder econômico, e aos poucos assimilar-se às condições da sociedade burguesa. No

31 Id. Ibid. p. 42; Id. Ibid. p. 315.

32 BENJAMIN. Proust-Papiere. In: GS II-3. p. 1054;

33 BENJAMIN, Walter. A imagem de Proust. In: Obras escolhidas I. Op. cit. p. 43; GS II-1. Op. Cit. p. 316. 
baile de máscaras do final de $O$ tempo redescoberto, quando já se transformara em passado distante o mundo anterior ao caso Dreyfus e à Grande Guerra, a composição mimética derradeira da burguesia endinheirada mas ávida por reconhecimento social com a aristocracia falida tem a sua irônica encenação no casamento da senhora Verdurin com o príncipe de Guermantes.

Ora, é o riso sarcástico e implacável de Proust dirigido a essa "sociedade saturada" que, para Benjamin, dá à obra proustiana a sua potência subversiva. Não tanto o humor como a sátira corrosiva - a "perigosa comicidade" ${ }^{4}$ - que atinge, um por um, os valores mais caros a essa ordem social: "a unidade da família e da personalidade, a moral sexual e a honra estamental". ${ }^{35}$ Mas a sátira subversiva de Proust se deixa ver antes de tudo - essa é a leitura de Benjamin - na exposição da linguagem desse mundo saturado, já que um dos sintomas paradoxais de sua saturação pode ser reconhecido justamente na proliferação da linguagem até a banalidade, no palavrório dos salões mundanos, nos códigos intrincados de cada salão, mas também na exaustão de uma língua artificial e reduzida à pura frivolidade. Por isso, Benjamin - que traduziu O caminho de Guermantes com todos os seus socioletos mundanos parodiados por Proust - considera que a preocupação que orienta a sátira proustiana é "reconstruir toda a estrutura da alta sociedade" - ou seja, da burguesia estabelecida e da aristocracia em declínio - "sob a forma de uma fisiologia da tagarelice". ${ }^{36}$ Pois o modo de Proust desmascarar pela sátira essa ordem social é expor mimeticamente o funcionamento de sua linguagem. Na verdade, o que há de mais subversivo no procedimento de Proust é a própria assimilação mimética dessa "linguagem secreta dos salões", a apropriação astuciosa dos códigos e idiomas da "sociedade saturada" com a finalidade justamente de submeter o mundo imitado com sua linguagem cifrada a uma virulenta sátira. As anedotas sobre a figura de Proust a que Benjamin se refere na segunda parte do ensaio aludem nada menos que a esse jogo mimético que Proust estabelece com os códigos prolixos e enredados da "sociedade saturada" e, assim, termina por desvelar, pelo pastiche e pela farsa, o seu risível funcionamento. ${ }^{37}$

34 Id. Ibid. p. 42; Id. Ibid. p. 315.

35 Id. Ibid. p. 43; Id. Ibid. p. 316.

36 Id. Ibid. p. 42-43; Id. Ibid. p. 315-316.

37 Numa dessas anedotas Benjamin liga o uso mimético e performativo da linguagem por Proust, inclusive em suas cartas, ao "esquema lendário" de um bilhete com o seguinte teor: "Minha honorável e graciosa Senhora, acabo de notar que esqueci minha bengala ontem em sua casa, e peço-lhe que a entregue ao portador deste escrito. P. S. Por favor, desculpe-me pelo incômodo, acabo de encontrá-la". 
$\mathrm{Na}$ verdade, nessa sua leitura da sátira social em Proust na segunda parte do ensaio, Benjamin mobiliza com insistência a duplicidade dialética da noção de mímesis, tal como ela pode ser reportada aos procedimentos miméticos de que Proust lança mão, procedimentos que se revelam, no fundo, um modo de operar importantíssimo em toda a obra proustiana, inclusive nos seus exercícios críticos de pastiches de outros escritores - tem-se assim, de um lado, a mímesis como um aprendizado ao mesmo tempo assimilativo e experimental do mundo que se deve, de qualquer modo, à função mimética da linguagem e que se faz presente, por exemplo, nas brincadeiras infantis baseadas na imitação, mas também faz lembrar os mecanismos de defesa de alguns animais que se misturam mimeticamente ao ambiente como estratégia de sobrevivência; de outro lado, mas inseparável da primeira significação, temos a mímesis como o jogo ativo e criativo de produção de semelhanças, que, nesse sentido, não se dá em termos de reprodução mas, antes, como criação de relações novas. Ora, esse movimento dúplice e dialético da capacidade mimética subjaz à teoria benjaminiana da mímesis $^{38} \mathrm{e}$ a sua compreensão ao mesmo tempo alargada e ambivalente do mimético percorre de algum modo todas as formulações da segunda parte do ensaio em torno da crítica satírica de Proust à sociedade burguesa. Com efeito, a mímesis como um aprendizado assimilativo pode sempre manifestar-se, no limite, sob a forma violenta e degradada da sujeição e do ajuste a uma heteronomia opressiva, quando então os mecanismos miméticos de defesa encontrados no mundo natural se reproduzem na vida social. Na Infância berlinense, ao refletir sobre esse aprendizado do mundo pela criança através de jogos com a linguagem, Benjamin aponta rapidamente o caráter violento de que pode se revestir o comportamento mimético quando ele se converte em esforço de adequação do sujeito a uma ordem social: "O dom de reconhecer semelhanças não é mais que um fraco resquício da velha coação de ser e se comportar semelhantemente. Não aquelas que me faziam semelhante a modelos de civilidade, mas sim às casas, aos móveis, às roupas". ${ }^{39}$

$\mathrm{Na}$ Recherche, o comportamento mimético como mecanismo de defesa e estratégia de sobrevivência aparece tanto no esforço dos burgueses emergentes em Id. Ibid. p. 43; Id. Ibid. p. 315-316.

$38 \mathrm{Cf}$. a respeito GAGNEBIN, Jeanne Marie. Do conceito de mímesis no pensamento de Adorno e Benjamin. In: Sete aulas sobre linguagem, memória e história. Rio de Janeiro: Imago, 1997. p. 82-104.

39 BENJAMIN. Infância berlinense por volta de 1900. In: Obras escolhidas II. $3^{\mathrm{a}}$ ed. Trad. de José Carlos Martins Barbosa. São Paulo: Brasiliense, 1995. p. 99; Berliner Kindheit um Neunzehnhundert. In: GS IV-1. p. 261. 
assimilar-se ao comportamento social dos salões aristocráticos quanto na tentativa da nobreza de adequar-se às novas condições da sociedade burguesa - o esnobismo, que Proust se esmera em radiografar, é a manifestação emblemática dessa busca de assimilação mimética na "sociedade saturada", tanto o esnobismo dos burgueses no seu afã de assimilar-se a sociedade de privilégios da aristocracia (como no clã dos Verdurin) quanto o esnobismo da aristocracia em declínio ao fingir calculadamente a despreocupação com a suas insígnias e mesmo flertar com a crítica burguesa aos valores aristocráticos (como na Sra. de Villeparisis ou em Saint-Loup). ${ }^{40}$ Mas as formas opressivas de comportamento mimético se manifestam também no modo como judeus e homossexuais buscam assimilar-se à ordem social que os recusa e este é um motivo ao qual Proust dedica várias páginas de $O$ caminho de Guermantes e de Sodoma e Gomorra. ${ }^{41}$ Segundo Benjamin, Proust de algum modo obedece ao movimento assimilativo ligado à atitude de sua classe social, mas, num autêntico movimento de astúcia da mímesis, ele termina por subverter essa assimilação numa posição mimética criativa e ao mesmo tempo crítica e deslocar a mecânica do mimetismo para a mímesis como produção de novas relações de semelhança. Essa posição se traduz nos procedimentos miméticos de que Proust se serve na sua obra, no uso que ele faz da metáfora como "condensação desse mesmo mimetismo" ${ }^{42}$ e, enfim, no "mundo em estado de semelhança", tal como ele o constrói na Recherche. Foi, com efeito, nos meios sociais "saturados" da França do fim do século XIX que Proust se instruiu no mimetismo e deles recolheu o seu procedimento mimético - "É

40 Uma importante sentença da segunda parte do ensaio diz: "A análise proustiana do esnobismo, muito mais importante que sua apoteose da arte, é o ponto alto de sua crítica social". BENJAMIN. A imagem de Proust. In: Obras escolhidas I. Op. cit. p. 43; GS II-1. Op. Cit. p. 316.

41 Numa das suas últimas cartas a Adorno, datada de 7 de maio de 1940, Benjamin comenta a cumplicidade entre o comportamento dos judeus franceses assimilados e o comportamento mimético dos homossexuais: "Quer me parecer que havia para Proust um modelo profundamente oculto (mas nem por isso inconsciente) dessa experiência fundamental: qual seja, o "não é isso" da assimilação dos judeus franceses. Você lembra a famosa passagem em Sodoma e Gomorra na qual a cumplicidade dod invertidos é comparada à constelação que define a conduta dos judeus entre si. O próprio fato de Proust ser meio judeu facultou-lhe o vislumbre da estrutura precária da assimilação; um vislumbre que Ihe foi sugerido externamente pelo caso Dreyfus". Hannah Arendt deu um desenvolvimento a essa formulação de Benjamin na sua leitura de O caminho de Guermantes e de Sodoma e Gomorra na primeira parte de Origens do totalitarismo, na qual apresenta a sua análise do antissemitismo moderno. Cf. ARENDT, Hannah. As origens do totalitarismo. Trad. de Roberto Raposo. São Paulo: Cia. das Letras, 1989. p. 101110.

42 BENJAMIN, Walter. A imagem de Proust. In: Obras escolhidas I. Op. cit. p. 44; GS II-1. OP. Cit. p. 318. Sobre esse mimetismo da metáfora proustiana, Benjamin fornece uma explicitação, ela também mimética e metafórica: "Suas cognições mais exatas e mais evidentes pousam sobre os objetos como insetos pousam sobre folhas, flores e galhos, sem traírem nada de sua presença até que um salto, uma batida de asas, um pulo, revelam ao observador assustado que uma vida própria havia se insinuado num mundo estranho, de forma incalcilável e imperceptível. 'A metáfora, por mais inesperada que seja', diz Pierre-Quint, 'adequa-se estreitamente à noção' ». Id. Ibid. ; Id. Ibid. p. 317-318. 
desse círculo social [o da aristocracia decadente e da burguesia assimilada aos hábitos aristocráticos] que deriva o mimetismo como procedimento do romancista". ${ }^{43}$

Segundo Benjamin, foi também na convivência com o ambiente mundano dos salões que Proust desenvolveu os vícios complementares da lisonja e da curiosidade, ambos vinculados à atitude mimética. A interpenetração fecunda da lisonja e da curiosidade se mostrava exemplarmente no interesse por ele desenvolvido pelo mundo dos empregados e dos serviçais (e não se pode esquecer a importância que têm os criados na Recherche, de Françoise a Jupien) - a proximidade com esse mundo the permitia observar as engrenagens da sociedade a partir do ponto de vista dos subalternos e assim ter acesso a perspectivas que não encontraria nos ambientes burgueses e aristocráticos. Em especial, a curiosidade se manifesta em Proust sob a forma de uma pulsão mimética ligada ao olhar - "voir e désirer imiter eram para ele uma e a mesma coisa", teria o escritor confidenciado certa vez. ${ }^{44}$ Há ao longo de toda a Recherche, como já se disse aqui, um privilégio especialmente concedido às experiências óticas e visuais, desde a obsessão do personagem-narrador por instrumentos óticos e pelo mundo do espetáculo teatral até as muitas cenas em que se torna manifesto o voyeurismo do herói (as duas mais importantes são, por certo, aquela em que ele, garoto, flagra pela janela a filha de Vinteuil com a sua amiga cuspir no retrato do pai já morto e, no início de Sodoma e Gomorra, aquela em que o jovem narrador espiona o jogo de sedução entre o barão de Charlus e Jupien). Mas esse privilégio concedido ao olhar e ao ótico se desdobra em procedimentos propriamente narrativos, nas perspectivas descontínuas abertas pelo narrador, nos deslocamentos de foco que ele promove. De todo modo, trata-se ainda do modo mimético de proceder do narrador proustiano e estes procedimentos têm cumplicidade com a pulsão visualnarrativa - o vício da curiosidade, diz Benjamin - que Proust desloca - uma vez mais, mimeticamente - para a sua técnica romanesca. Não se pode, aliás, desconsiderar aqui que o mundo retratado na Recherche é também o mundo nascido sob o impacto das transformações estéticas, tecnológicas e midiáticas do século XIX com a invenção das mídias visuais da fotografia e posteriormente do cinema.

43 Id. Ibid.; Id. Ibid. p. 317.

44 No seu "Diário parisiense" escrito no período de sua estadia na capital francesa traduzindo Proust, Benjamin desenvolve mais longamente esse tema e se refere mesmo a uma "curiosidade sádica" em Proust. Cf. BENJAMIN. Pariser Tagebuch. In: GS IV-1. p. 578. Ernani Chaves desenvolveu esse tema no seu ensaio "Walter Benjamin, Marcel Proust e a questão do sadismo". CHAVES, Ernani. Walter Benjamin, Marcel Proust e a questão do sadismo. In: No limiar do moderno. Estudos sobre Friedrich Nietzsche e Walter Benjamin. Belém: Paka-tatu, 2003. p. 119-144. 
Mas no final da segunda parte do ensaio, no marco da sua leitura políticomaterialista de Proust, Benjamin confere uma função singularmente subversiva à curiosidade proustiana, função subversiva que se expressa no "elemento detetivesco" dessa curiosidade (detetive particular em inglês é, aliás, private-eye). Ao devassar com seu olhar detetivesco a "sociedade saturada" do fim do século XIX, na qual o triunfo do capitalismo industrial se mistura à agonia do feudalismo, Proust acaba por desvendar, a partir da esfera da intimidade burguesa e da vida mundana dos salões, o funcionamento das castas ociosas que se mantinham das composições precárias entre burguesia e aristocracia. É por isso que, para Benjamin, o olhar de detetive de Proust expõe essas classes como "um clã de criminosos, uma quadrilha de conspiradores, com a qual nenhuma outra poderia comparar-se: a Camorra dos consumidores". ${ }^{45}$ É ainda à interpretação lukacsiana para as contradições da consciência burguesa no alto capitalismo que Benjamin apela para ler Proust com as preocupações de uma crítica política materialista. Com efeito, a "sociedade saturada" da Recherche - como seus aristocratas deslocados e viciosos, seus burgueses ociosos e diletantes, vivendo de privilégios do passado ou de rendas de família precisa escamotear permanentemente a inscrição perversa no sistema produtivo dos seus membros como 'puros consumidores' que equivalem, portanto, a 'exploradores puros'. A síntese notável dessa leitura política materialista se encontra no último parágrafo da segunda parte do ensaio: "Proust descreve uma classe obrigada a dissimular integralmente a sua base material, e que em consequência precisa imitar um feudalismo sem significação econômica, o qual, por isso mesmo, é tanto mais utilizável como máscara da grande burguesia". ${ }^{46}$

Mas essa descrição proustiana se realiza a partir dos meandros e bastidores dessa sociedade, das suas mais íntimas engrenagens, das suas zonas de sombra, dos seus pontos cegos, e, no fim das contas, a partir da figura de um 'eu' produzido nas condições dessa "sociedade saturada", um 'eu' em busca das imagens fragmentárias que lhe permitam compor e narrar de algum modo a sua história -

Como se deve compreender o meio de Proust. Em primeiro lugar, seu livro não é um romance social no sentido em que nele um indivíduo tomaria posição em relação ao acontecido. Sua obra é a 'socialização' literária do eu. Como a sociedade faz funcionar o eu - e qual sociedade faz funcionar o eu. Como ela

45 BENJAMIN, Walter. A imagem de Proust. In: Obras escolhidas I. Op. cit. p. 45; GS II-1. Op. Cit. p. 319.

46 Id. Ibid. p. 46; Id. Ibid. 
procede: graças a uma destruição que se realiza na memória. O que assim é feito: uma sociedade burguesa em declínio, que é submetida pelas forças não vencidas da sociedade feudal ${ }^{47}$,

resume Benjamin, agora numa decisiva nota preparatória para a redação do ensaio.

Já que o que está em jogo na Recherche é "'socialização' literária do eu”, uma leitura materialista da obra de Proust, tal como Benjamin a propõe, deve concentrarse, portanto, na materialidade histórica singular da língua poética aí criada para que esse eu forjado no auge da sociedade burguesa se deixasse narrar. Essa orientação materialista da leitura crítica Benjamin a vê confirmada num comentário do crítico Proust acerca da sintaxe de Flaubert. Um comentário que Benjamin aponta como um pequeno mas precioso exemplar de crítica materialista, "mais valioso que a maioria das coisas que existem neste domínio", ou seja, o domínio do "estudo literário de orientação histórico-materialista". ${ }^{48}$ Trata-se, com efeito, de uma observação que encontramos no ensaio de Proust "A propósito do estilo de Flaubert":

Amamos estes materiais pesados que a frase de Flaubert eleva e deixa cair com o barulho intermitente de uma escavadeira. Pois, se, como alguém escreveu, a lâmpada de Flaubert acesa na noite servia de farol para os marinheiros, pode-se dizer também que quando 'descarregou' suas frases, estas vinham com o ritmo regular de uma dessas máquinas de terraplanagem. Felizes os que sentem esse ritmo obsedante. ${ }^{49}$

Robert Kahn chama a atenção para o fato de que Proust associa a frase de Flaubert precisamente ao ritmo intermitente de uma máquina, quando este último escreveu em plena Revolução Industrial. ${ }^{50}$ Para o crítico materialista, trata-se mesmo de desvendar na materialidade da língua inventada pelo escritor, na sua sintaxe e no ritmo de sua frase, os efeitos concretos, os ecos, as ressonâncias e mesmo os choques advindos de seu momento histórico. No seu ensaio de 1929 sobre Proust, Benjamin se propôs a realizar esse modo de leitura histórico-materialista em relação à obra proustiana. No ritmo alongado ao extremo, insistente, entrecortado, por vezes agônico da frase proustiana, Benjamin reconhece o temor da asfixia provocado pela asma do escritor mas também, acima de tudo, a inquietação diante da ameaça sempre presente da morte -

47 BENJAMIN. Proust-Papiere. In: GS II-3. Op. cit. p. 1060.

48 Id. Ibid. p. 1050; Id. Ibid. 48.

49 BENJAMIN. Passagens. Op. Cit. p. 439; Das Passagen-Werk. In: GS V-1. Op. cit. p. 498-499. Cf. também Proust-Papiere. In: GS II-3. p. 1051; Cf., por fim, PROUST, Marcel. A propósito do 'estilo' de Flaubert. In: Nas trilhas da crítica. Trad. de Plínio Augusto Coelho. São Paulo: Edusp, 1994. p. 76-77.

50 Cf. KAHN, Robert. Images, passages: Marcel Proust et Walter Benjamin. Op. cit. p. 83. 
Essa asma penetrou em sua arte, se é que sua arte não a tenha criado. Sua arte imita o ritmo desse temor ante a asfixia. E sua reflexão irônica, filosófica, didática, é sempre a sua maneira de recobrar o fôlego quando se liberta dos demônios de suas rememorações. Num nível mais amplo, porém, era a morte que ele tinha constantemente presente, sobretudo quando escrevia - a crise ameaçadora, sufocante..$^{51}$

Ora, a matéria fundamental do romance de Proust é não a memória involuntária e a feliz revisitação ao passado perdido mas, ao contrário, o poder de destruição do tempo e a onipresença ameaçadora da morte e, em face deles, as respostas frágeis, precárias, inacabadas da palavra do narrador e da obra da escrita. Mas não apenas isso: o auge da modernidade industrial, momento histórico em que Proust escreve a sua Recherche, é um tempo de onipresença da experiência da morte, seja pela imposição generalizada da temporalidade da produção e do consumo de mercadorias que confere às experiências um caráter de fugacidade e de futilidade, seja pela destruição das formas tradicionais de experiência e de linguagem que aí tem lugar, seja, em contrapartida, pelas desconcertantes transformações estéticas, linguísticas e midiáticas que promovem uma ruptura violenta entre o antigo e o novo. Nesse sentido, o temor frente à ameaça constante da morte que, segundo Benjamin, penetra na sintaxe de Proust não diz respeito apenas ao medo de não completar a sua obra mas ao esforço agônico de reter fragmentos da história vivida diante da percepção da veloz destruição de todas as experiências, sendo esta justamente a marca da experiência histórica da modernidade que se imprime na língua da Recherche e na qual o crítico materialista precisa aprofundar-se.

Para Benjamin, a língua poético-narrativa inventada para a Recherche busca dar a forma de uma tateante e fragmentária rememoração narrativa àquela experiência do involuntário como aquilo que escapa à vontade consciente do sujeito e resta esquecido no próprio corpo e nas suas camadas de sensações inconscientes. Proust teria inventado, assim, uma língua narrativa para a corporeidade produzida na modernidade burguesa com tudo o que essa corporeidade guarda de memória involuntária e de esquecimento. Não há como não lembrar aqui do parágrafo inicial do ensaio sobre $O$ narrador no qual a descrição da crise moderna da narração é associada ao emudecimento dos combatentes da Primeira Guerra que já não dispunham da capacidade de comunicar experiências e, portanto, de transformar o

51 BENJAMIN, Walter. A imagem de Proust. In: Obras escolhidas I. Op. cit. p. 49; GS II-1. Op. Cit.p. 323. 
vivido em história. Essa destituição de experiências narráveis encontra sua figuralimite na guerra tecnológica do início do século $X X$, na qual o "frágil e minúsculo corpo humano" é exposto, como nunca antes, a um "campo de forças de torrentes e explosões". ${ }^{52}$ Mas essa foi apenas a radicalização de uma experiência que já era a dos homens da alta modernidade industrial com seus corpos disciplinados na crescente aparelhagem técnica da sociedade moderna. Essa mesma dificuldade de narrar é também a do eu da Recherche que busca recompor a sua história a partir da montagem de fragmentos da memória involuntária. ${ }^{53}$

Não por acaso Benjamin conclui o seu ensaio sobre Proust se referindo precisamente à língua mimético-corporal inventada por Proust para realizar a sua recherche: "(...) suas frases são a totalidade do jogo muscular do corpo inteligível, contém todo o esforço indizível necessário para erguer o que foi capturado". ${ }^{54}$ A tarefa narrativa que se impôs ao narrador proustiano foi a de dar voz e forma narrativas ao não-conciliado e ao esquecido a partir das "proto-imagens históricas" 55 da memória involuntária de um eu que, nas condições da alta modernidade burguesa, busca juntar e compor os cacos de sua história. O crítico Benjamin deseja auscultar os ecos dessa "historiografia inconsciente" ${ }^{56}$ que ressoa na Recherche de Proust. Por isso, é ainda essa "historiografia inconsciente" da Recherche que o crítico-historiador materialista retoma e mobiliza em sua "arqueologia da modernidade" do século XIX. Para esse projeto, a obra literária não constitui um mero documento histórico, "um simples material para a historiografia"; ao contrário, ela é convertida num "organon da história" ${ }^{77}$ - um médium histórico-linguístico no qual o ainda não expresso pode alcançar uma expressão singular.

52 BENJAMIN. O narrador. In: Obras escolhidas I. Op. Cit. p. 214; GS II-2I. Op. cit. p. 439.

53 Retomo aqui uma conclusão do meu trabalho de doutorado e do meu artigo Benjamin e a imagem proustiana. Cf. OLIVEIRA, Luís Inácio. Benjamin e a imagem proustiana. In: Revista Limiar. Dossiê Walter Benjamin: materialidade, arte e história. V. 03, N. 6, 2016. p. 325-326.

54 BENJAMIN. A imagem de Proust. In: Obras escolhidas I. Op. cit. p. 45; GS II-1. Op. Cit. p. 319.

55 ADORNO, Theodor W. Posição do narrador no romance contemporâneo. In: Notas de literatura I. Op. Cit. p. 62.

56 Recorremos aqui à concepção de Adorno segundo a qual as obras de arte podem constituir uma 'historiografia inconsciente'. Cf. BENJAMIN. Teoria estética. Lisboa: Edições 70, 1988. p. 217.

57 BENJAMIN, Walter. Literaturgeschichte und Literaturwissenschaft. In: GS III. Op. cit. p. 290; Histoire littéraire et science de la literature. In: Oeuvres II. Op. cit. p. 283. 


\section{Referências bibliográficas}

ADORNO, Theodor W. Notas de literatura I. Trad. de Jorge de Almeida. São Paulo: Duas cidade/Editora 34, 2003.

. Teoria estética. Trad. de Artur Morão. Lisboa: Edições 70, 1988.

ARENDT, Hannah. Origens do totalitarismo. Trad. de Roberto Raposo. São Paulo: Cia. das Letras, 1989.

BENJAMIN, Walter. Gesammelte Shriften. Frankfurt am Main: Suhrkamp, 1991.

Obras escolhidas I. Magia e técnica, arte e política. Trad. de Sergio Paulo Rouanet. São Paulo : Brasiliense, 2012.

. Obras escolhidas II. Rua de mão única. Trad. de Rubens Rodrigues Torres Filho et alii. São Paulo : Brasiliense, 2012.

Obras escolhidas III. Charles Baudelaire, um lírico no auge do capitalismo.

Trad. de José Carlos Martns Barbosa et alii. São Paulo : Brasiliense, 1994.

. Passagens. Trad. de Irene Aron. Belo Horizonte/São Paulo: UFMG/Imprensa Oficial, 2006.

BLANCHOT, Maurice. O livro por vir. Trad. de Leyla Perrone-Moisés. São Paulo: Martins Fontes, 2005.

CHAVES, Ernani. No limiar do moderno. Estudos sobre Friedrich Nietzsche e Walter Benjamin. Belém: Paka-tatu, 2003.

GAGNEBIN, Jeanne Marie. Sete aulas sobre linguagem, memória e história. Rio de Janeiro: Imago, 1997.

Limiar, aura e rememoração. Ensaios sobre Walter Benjamin. São Paulo: Ed. 34, 2014.

GREFFRATH, Krista. Metaphorischer materialismus. Untersuchungen zum Geschichtsbegriff Walter Benjamins. München: Wilhelm Fink Verlag, 1981.

. Proust et Benjamin. In: WISMANN, Heinz (org.). Walter Benjamin et Paris. Walter Benjamin et Paris. Paris: Cerf, 1986.

KAHN, Robert. Images, passages: Marcel Proust et Walter Benjamin. Paris : Kimé, 1998.

PROUST, Marcel. À la recherche du temps perdu. Bibliothèque de la Pleiade. Paris: Gallimard, 1987. (3 volumes). 
Em busca do tempo perdido. Trad. de Fernando Py. Rio de Janeiro: Ediouro, 2002. (3 volumes).

- Nas trilhas da crítica. Trad. de Plínio Augusto Coelho. São Paulo: Edusp/Imaginário, 1994.

RICOEUR, Paul. Tempo e narrativa II. A configuração do tempo na narrativa de ficção.

Trad. de Márcia Valéria Martinez de Aguiar. São Paulo: Martins Fontes, 2012. 